K. A. Chernyshev ${ }^{\text {a) }}$

a) Vyatka State University

\title{
DEMOGRAPHIC FACTORS AND LOCAL GOVERNMENT REFORM ${ }^{1}$
}

The subject of the article is to analyze the changes in the grid of municipalities in the Russian Federation during the reform of local government under the influence of demographic factors. The research based on a systems approach to the investigation of the regions where there is interaction between demographic and government subsystem. The main research method was to analyze the legislation and regional statistics. Detailed analysis of the demographic situation in the Kirov Oblast, the impact of natural and the migration decrease on change in the territorial organization of local self-government in the region are analyzed. The prospects of development of the municipal division under the influence of population are defined. It is concluded that in the present time, the grid municipalities in depopulated regions of Russia are not stable and will continue to vary according to the dynamics of population.

1 C Chernyshev K. A. Text. 2015. 
Keywords: municipal reform, municipalities, territorial organization of the population, the demographic situation, Kirov Oblast

An important condition for rational territorial organization of control is the optimal combination of centralization and decentralization. Accordingly, in the Russian Federation the local government is recognized and guaranteed, which is a key institution of a democratic society, one of the foundations of the constitutional system. In 2003, with the adoption of the Federal Law № 131-FZ «On General Principles of Local SelfGovernment in the Russian Federation» (hereinafter the Federal Law № 131) started the modern phase of the reform, which marked a qualitative change of the local self-government in the country. Despite significant period of implementation, the reform is not completed yet and did not reach their goals, that is recognized at the highest level. The Russian President Vladimir Putin spoke on this issue in the last address to the Federal Assembly: «I think the most important task is to clarify the general principles of the local self-government organization, and develop strong, independent, financially sustainable local authorities. And we need to start this work and give it sounds legal foundations next year, 2014». Targets municipal reform during the years of its implementation have not changed: the development of government close to the population, resolving the most of the crucial issues of its livelihood: «local authority should be close to the people - should be organized so, that any citizen could reach out to it, figuratively speaking» [7].

The actual practice of the local government reform is not consistent throughout the ideal representations. In the course of reform in Russia, a unified structure of territorial organization of local self-government was created, which at the end of the transitional period (1 January 2009) included 24161 municipality, of which 507 urban districts, 1810 municipal districts, 1,745 urban settlements, 19.863 rural settlements intercity and 236 intra-city territory of a federal city. Increase in the number of municipalities in the reform due to the desire to bring the local authorities to the local community, which prevailed over the need to ensure economic sustainability of municipalities.

After the entry of the Federal Law № 131 fully formed system of municipalities has been very mobile, primarily at the settlement level (Table 1). To the first approximation, this was because the development of the system of local government was based on the administrative-territorial units existed in the Soviet period, the discrepancy which changed conditions of settlement, manage- ment and governance noticeably manifested at the grassroots level, which resulted in at this stage, priority was to reduce the number of settlements.

A more detailed analysis of the reduction in the number of municipalities in the first level after the 2009 , value was the combined effect of both economic and demographic factors. The first of these appeared in the fact, that newly created municipalities faced a number of financial problems described in detail in the literature $[4,8,12]$. The essence of the economic factor is the many of the settlements were not viable due to the lack of necessary economic potential and tax base, chronic depending on higher budgets, poor infrastructure. Own income is sometimes not enough to pay the salaries of the increased municipal employees. Back in the early reform, there was an idea of the transmission of social obligations to local governments, which increased local spending, while revenues have limited Tax Code [13].

Relevance to local authorities as closest to the people involves matching the existing system of settlement, taking into account population dynamics. Therefore, a serious problem in some regions of Russia, which has become a manifestation of the demographic factor was the lack of population of municipalities. Decrease in population within the boundaries of the grassroots units of the administrative and territorial structure compared with the Soviet period largely restricts financial opportunities created within their boundaries of municipalities.

The study of such transformations based on the system representation of the regions considered as integral territorial socio-economic systems, which combine all spheres of life of the population [6]. Regions are represented as a set of

Table 1

Dynamics of the number of municipalities in Russia (at the beginning of the year)

\begin{tabular}{|l|c|c|}
\hline & 2009 r. & 2013 r. \\
\hline Municipalities & 24161 & 23001 \\
\hline municipal districts & 1810 & 1817 \\
\hline urban okrug & 507 & 518 \\
\hline intra-city territory of a federal city & 236 & 257 \\
\hline settlement & 21608 & 20409 \\
\hline urban settlements & 1745 & 1687 \\
\hline rural settlements & 19863 & 18722 \\
\hline
\end{tabular}

* excluding the municipalities of the Chechen Republic and the Republic of Ingushetia, where the transition period was extended until 2010. 
Table 2

Leading regions to reduce the number of rural and urban settlements during 2009-2013 [9]

\begin{tabular}{|l|c|c|c|c|c|c|c|c|}
\hline \multicolumn{1}{|c|}{1} & 2 & 3 & 4 & 5 & 6 & \multicolumn{2}{c|}{$\mathbf{2 0 1 3}$ г. } \\
\hline & \multicolumn{3}{|c|}{$\mathbf{2 0 0 9}$ r. } & \multicolumn{4}{c|}{8} \\
\hline Federal subjects & settlement & $\begin{array}{c}\text { urban } \\
\text { settlements }\end{array}$ & $\begin{array}{c}\text { rural } \\
\text { settlements }\end{array}$ & settlement & $\begin{array}{c}\text { urban } \\
\text { settlements }\end{array}$ & \multicolumn{2}{c|}{$\begin{array}{c}\text { rural } \\
\text { settlements }\end{array}$} & $\begin{array}{c}\text { column 5/ } \\
\text { column 2 }\end{array}$ \\
\hline Sakhalin Oblast & 6 & 3 & 3 & 3 & 2 & 1 & 0,50 \\
\hline Kostroma Oblast & 273 & 12 & 261 & 150 & 12 & 138 & 0,55 \\
\hline Nizhny Novgorod Oblast & 610 & 78 & 532 & 362 & 64 & 298 & 0,59 \\
\hline Novgorod Oblast & 199 & 21 & 178 & 127 & 21 & 106 & 0,64 \\
\hline Kursk Oblast & 507 & 27 & 480 & 322 & 27 & 295 & 0,64 \\
\hline Penza Oblast & 400 & 24 & 376 & 295 & 24 & 271 & 0,74 \\
\hline Vologda Oblast & 344 & 22 & 322 & 274 & 22 & 252 & 0,80 \\
\hline Kirov Oblast & 403 & 53 & 350 & 326 & 53 & 273 & 0,81 \\
\hline Pskov Oblast & 218 & 26 & 192 & 181 & 25 & 156 & 0,83 \\
\hline Ivanovo Oblast & 154 & 25 & 129 & 129 & 24 & 105 & 0,84 \\
\hline
\end{tabular}

more specific subsystems, heterogeneous, but interconnected, functioning on the basis of the total area. They include the regional economy, infrastructure, regional finance, management system, etc., occupies a central position demographic subsystem (regional community population). The changes of regional systems can be both evolution and degradation.

Local government is one of the territorial structures emerging from regions, which, nevertheless, is poorly known in terms of the features of a given territory, and its relations to the resettlement is not considered at all [5]. Connection of the demographic factor to the dynamics of the territorial organization of local government in the course of municipal reform is manifested differently in each territory of the subjects of the Russian Federation, which is explained by regional characteristics and reasons, both objective and subjective.

Demographic situation in Russian regions with high dynamics reduction settlement network (Table 2) has similarities and differences. These regions with predominantly Slavic population in the period 2009-2012 differed sustainable natural decrease and population decrease. Annual migration increase was observed only in the Ivanovo and Nizhny Novgorod regions. In some years, migration gained not exceeding the natural population decrease was observed in Kursk, Pskov, Novgorod, Vologda, Penza regions. Kostroma Oblast characterized by population decrease, as due to the negative migration balance, and due to losing the leading role. Sakhalin Oblast, as for all the regions of the Far East, is characterized crucially in reducing the population migration factor. In the Kirov Oblast, during the period under review, there was a decrease in mortality and improving fertility and migration loss, due to the rise in fertility and decrease in mortality since 2010 was decisive in reducing the population. In these ten subjects of the Russian Federation fell bulk reduction municipalities' settlement level.

The regions of Russia, where there was a decrease in population, the main forms of conversion of municipalities of the first level was the consolidation of settlements together to form a larger municipalities joining the urban district, as well as changing the status of the settlement from the city to rural. One of the forms of a territorial reorganization was the formation of municipalities within the boundaries of the former municipal districts, urban districts, as this type of municipals cannot be divided into settlements. In fact, it means giving up a two-level system of municipalities and creating conditions for the separation of the public and local authorities. This path went in a number of regions of Russia, which currently have the lowest number of settlements (Sverdlovsk Oblast, Sakhalin Oblast).

The impact of demographic processes (primarily depopulation) of the territorial organization of local self-government should be considered in each region specifically, in this paper it will be illustrated on the example of Kirov Oblast.

Kirov Oblast is a region with a complex demographic situation, which is complicated by the natural decrease in migration outflow. The result is a long-term trend of population decrease. Beginning with the post-war period, the number of inhabitants decreased due to the declining birth rates and migration due to loss of population, especially in rural areas. The exception was in 19831993, which were characterized by a slight annual increase in population of the region. Since 1994, 


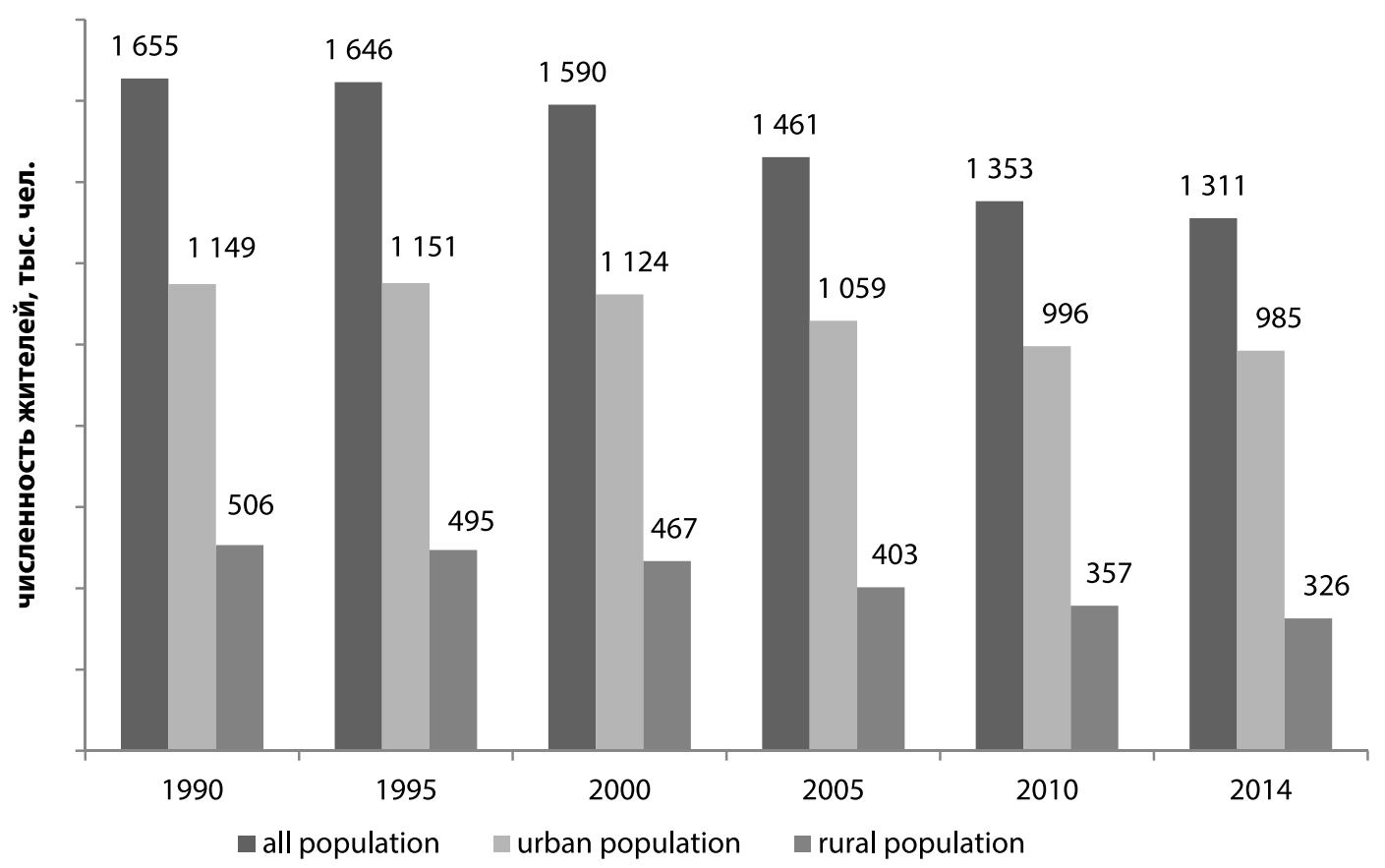

Fig. 1. Population Kirov Oblast in 1990-2014 (beginning of the year)

again there was an annual reduction of the population. In 1993, the population was 1 million 655 thousand people, by 2014, the population was a little over 1.3 million (Fig. 1).

Between 1993 and in 2013, when the average resident population of the area in the post-Soviet period was the highest, the population of the region decreased by 340.1 thousand people or by $20.6 \%$, while the urban population has decreased by $14.6 \%$, agriculture by $34.2 \%$. According to Rosstat forecasts, the trend of population decrease will continue in the coming decade, and its number in 2015 will be 1295.7 thousand; in 2025 - 1153.8 thousand people [3]. Major role in reducing the population of the region in 1994-2012 were natural decreased, which first emerged in the postwar period in 1991 (a year earlier than the national average). Since that time, mortality and natural decrease increased annually up to 2003. In 1991 and 1999 partially make up for the natural decrease in positive net migration, however, since 2000 , has been observed migration loss again.

The most tragic for the Kirov Oblast by the ratio of mortality and fertility was 2003 when the number of deaths was more than 2.1 times greater than the number of births. In terms of fertility decrease and the subsequent aging of the population, the increase of total mortality was inevitable. Rise in births in the region started in 2000, and a reduction in mortality started from 2004 . In the countryside, because of the age structure of the population, there was difficulties in obtaining health care, mortality and natural loss are higher than in urban areas. Least complicated de- mographic situation was observed during the analyzed phase forming a grid of municipalities in Kirov, Afanasyevsky districts. In the last two municipalities, in some years there was a small natural population growth. At the opposite side was Sanchursk district (mortality regarded a period of nearly three times higher than the birth rate). Compared to the 1990s and early 2000s, the demographic situation improved. Generally in the region in 2013, the birth rate, death rate, and natural population decrease were, respectively, 13.6, 15.4 and 2.4 people per 1 thousand inhabitants, for the first time in many years, in some areas, and the regional center marked with natural increase.

For the analysis of the demographic changes in the municipalities of great importance is the analysis of intraregional migration. If the natural decrease in development grid municipalities observed in all the areas, the territorial differences in migration are more pronounced. Migration has contributed significantly to the reduction of the population of peripheral areas.

The main volume of migration occurs within the area and is an example of the rise of the polarization space, assuming the concentration of population and activities in isolated foci in social desertification intra-periphery. If in 2006, a positive migration balance was noted in seven municipalities and the city of Kirov, the 2012 increase was observed only in the regional center and its neighboring areas. In general, during 2006-2012 years. Positive net migration had only Kirov, Slobodskoy and Orichevsky districts in the latter is due to the construction of the plant for the destruction 


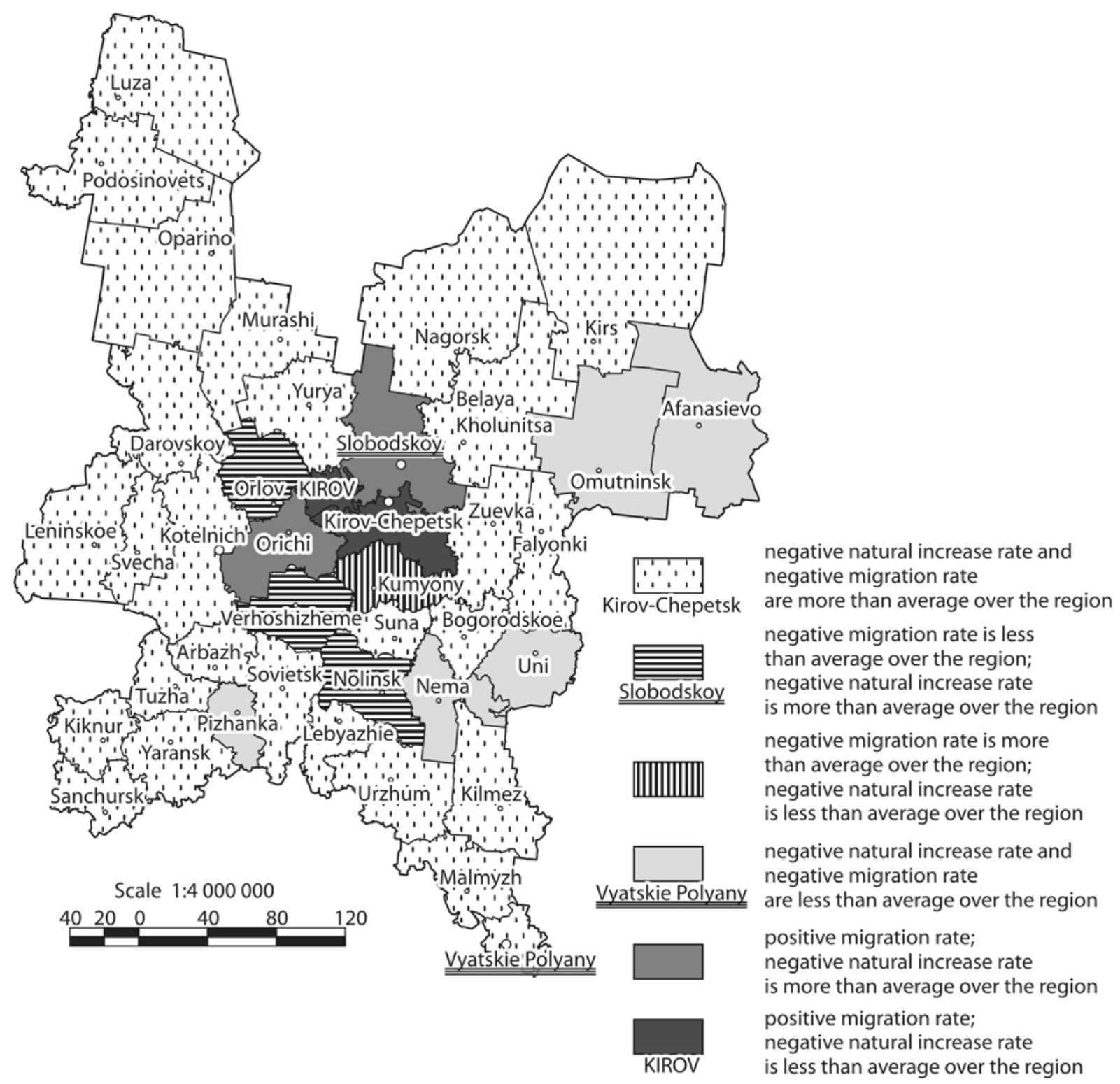

Fig. 2. Demographics during the formation of the structure of municipalities in the Kirov Oblast

of chemical weapons. Greatest value exodus during the period reached in peripheral Tuzhinsky, Falensky, Afanasyevsky districts (11-12\% of the residents at the beginning of 2006). Migratory activity of the rural population is higher than urban, so mechanical growth of intraregional and international migration in urban areas fully compensated migration loss to other regions of Russia. The main source of migration loss for the region as a whole is leaving to other subjects of the Russian Federation. Negative migration balance is celebrated with all federal districts, except Far East, and in some years, the Siberian and North Caucasus. The balance of international migration by positive exchange with a number of CIS countries and Vietnam [10].

The peculiarities of the demographic situation in the period of formation of structure all munic- ipalities and urban districts Kirov can be divided into six types (Fig. 2). Displayed on the map not only the demographic situation in the regions, but also in urban districts because of their participation in intraregional migration. Less problem areas cover mainly the central part of the area.

The current demographic situation, reducing the size and structure of the population has led to changes in other regional subsystems, including the system of local government. During preparation and holding of municipal reform in the region coincided with the decrease in natural wastage and increasing the value of migration loss (Fig. 3).

On the territory of the Russian Federation (except for the Chechen and Ingush republics) FZ № 131 fully entered into force on January 1, 2009 (the time before that was called the transitional period). However, Kirov region was among the first 


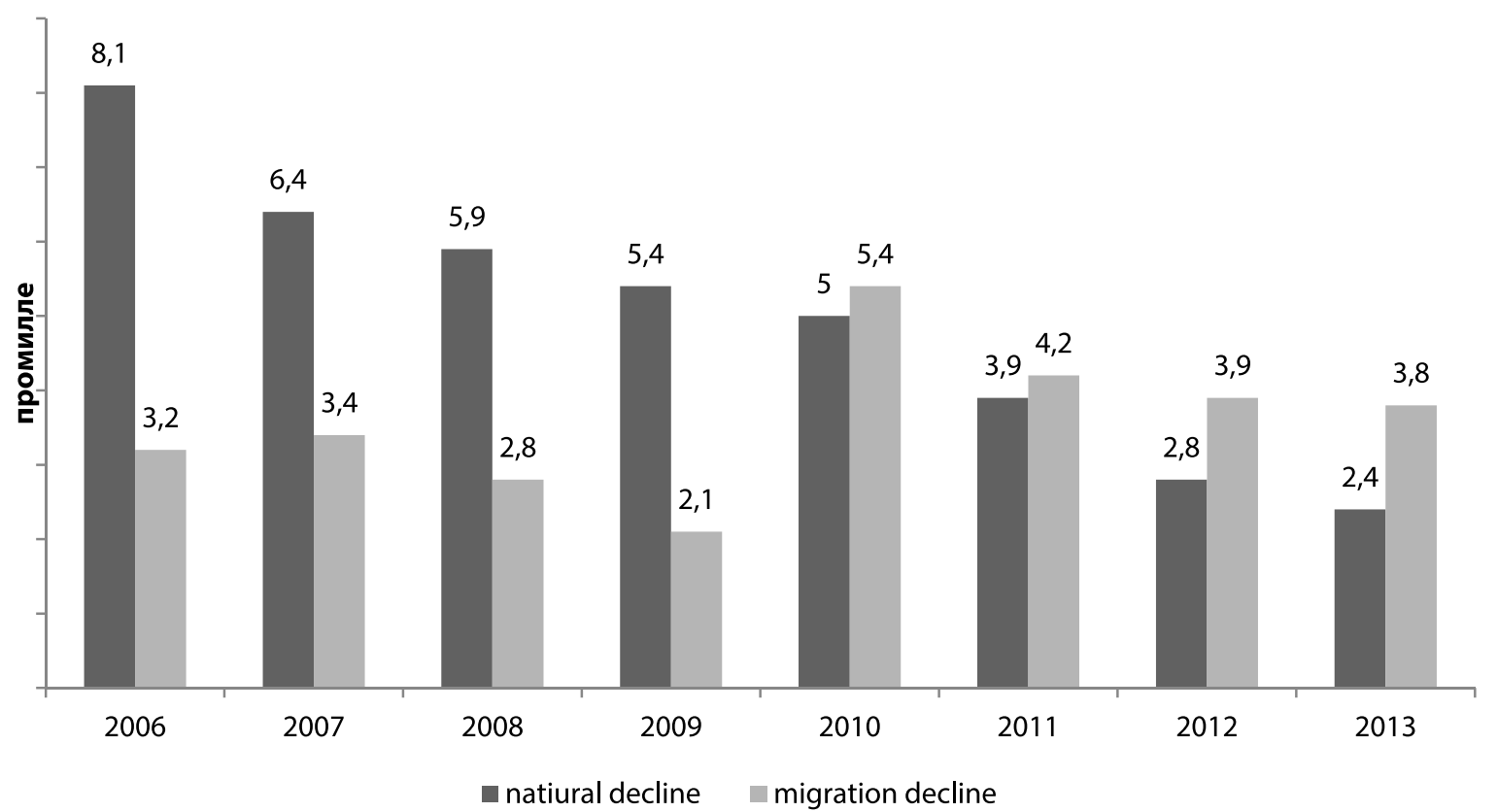

Fig. 3. Population decrease Kirov Oblast on components 2006-2013

46 subjects of the Russian Federation, where the mesh municipalities were formed earlier, in 2005, which allowed them to work from the beginning of 2006 to the end, the development of the Federal Law number 131 in the Kirov Oblast in December 2004, the Law «On establishing the municipal boundaries of the Kirov Oblast and empowering their status as municipal district, urban district, urban settlements, rural settlement» [2].

Theoretically, the territorial organization of local self-government in the Kirov Oblast was to be implemented on the basis of criteria defined by federal law:

1) population - within the boundaries of the rural settlement may be a village with a population more than 1,000 people and (or) the combined in total territory several villages with populations less than 1,000 people;

2) accessibility - borders of a settlement, which is composed of two or more localities, are established for people in all localities included in the settlement according to a pedestrian accessibility to the administrative center of rural settlement and back home during a day, and the borders of a municipal district are made for residents of all settlements within the municipal district according to a transport accessibility to the administrative center of the municipal district and back home during a day.

The practice of reform, drawing on existing grid of administrative-territorial local authorities assumed approximation to the population. Most of the newly created municipal settlements territorially corresponded to already existed rural counties (as well as the urban-type settlements, cities) that existed in the 1990s, when the number of rural administrations was almost constant.

At the initial stage of forming a grid of municipalities in the region, according to the Law of the Kirov Oblast «On establishing the municipal boundaries of the Kirov Oblast and empowering their status as municipal district, urban district, urban settlements, rural settlements» on December 7, 2004 № 284-LP was created two-tier mesh, which included 403 rural, 64 urban settlements, 39 municipalities and 6 urban districts. Number of first-level municipalities districts of the region differed markedly - from 23 in Urzhumsky district to 5 in Arbazhsky and Shabalinsky districts.

In accordance with the changes of settlement in the region, newly created municipalities was subjected to audit. A large number of municipalities on the background of the demographic situation described predetermined unsustainability of a significant number of rural settlements at the stage of creation. Within the borders of rural settlements were created rural districts, which later merged with the neighborhood districts. At the beginning of 2014, the most sparsely populated municipalities of the region were Prozorovskaya rural settlement with the Soviet district of 174 residents. Clearly, in view of the age composition, education level and characteristics of employment of residents, such settlements is difficult to form a local government and address issues of local importance. Subsequently, this led to a reduction in the number of rural settlements by combining together or accession to urban settlements. Because of the reforms of local government there were a large critical changes of urban settlements. In 
2005-2006, 11 urban-type settlements had 0.8 to 2 thousand inhabitants, and are endowed with the status of urban settlements, have been converted into rural areas. Changing the status of the settlements was well founded and only legislate transformation occurred in the fate of these settlements, and also gave certain benefits to residents.

Depopulation of the peripheral area by combining migration loss depopulation and aging population went slightly faster than this process reflected in the current statistical data, especially as the administration of rural settlements often tended to overstate permanent population. Therefore, after the census in 2010, the data on population size of existing settlements were refined and led to a new wave of cuts. Currently, enlargement in four areas located in different parts of the region has led to the fact that they have only one rural and one urban settlement (regional center). In the Orel region, one decree united eight rural settlements into one. The existence of such municipal districts is not contrary to the law, but there is no certainty that such territorial organization of local self-government can ensure the effective execution of local government issues of livelihood. The development of such large settlements on the territory remove government from the local population, whose interests it should represents, and does not meet the criterion of accessibility of the municipality center specified in the Federal Law № 131.

Highest revision in the years 2005-2013 undergone grid rural settlements. This is not surprising, the region is characterized by one of the highest rates of decrease in the Russian rural population. Laggards in the post-Soviet period marked only marginal subjects of the Far East and the European North (Magadan and Murmansk regions, Chukotka and Nenets Autonomous Okrugs), where there was a great migration loss, as well as in Pskov Oblast, the most demographically problematic area of the country.

Already at the stage of development of number of municipalities, they did not meet the criterion of accessibility center of the settlement. The most striking examples are typical for Verkhnekamsky district, the largest area. So, in the Lesnoy urban settlement of the area included villages far from the center more than $100 \mathrm{~km}$ and geographically located in the Perm Oblast. The formation of these municipalities happaned to be due to the existing system of settlement in the region and does not contradict to the Federal Law number 131, where it is noted that « these requirements in accordance with the laws of the Russian Federation may not be used in areas with a low density of rural pop-
Table 3

The average population in the municipalities of the Kirov Oblast of Russia and (beginning in 2013)

\begin{tabular}{|l|c|c|}
\hline & Russian Federation & Kirov Oblast \\
\hline rural settlements & 1,8 & 1,0 \\
\hline urban settlements & 13,9 & 6,7 \\
\hline municipal districts & 31,7 & 16,3 \\
\hline urban okrug & 133,1 & 114,1 \\
\hline
\end{tabular}

ulation as well as in remote and inaccessible areas» $[1]$.

Demographics impact on the average size of municipalities. A distinctive feature of the municipalities of the first level in the Kirov region is their relative uncrowded (Table 3).

Changes in the population of urban and rural settlements lead to a decrease in population of municipalities. However, at this level of the municipal unit demographic factor has not yet led to any territorial changes. The territorial division of the region remained stable since 1968. However, the authorities and the regional community are becoming increasingly apparent inevitability of this review and municipal level device while maintaining current demographic trends. During the implementation of the reform of the system of administrative, the territorial division of the Soviet period was inherited and modern grid municipalities second level, i.e. municipal districts were formed within the boundaries of the Soviet administrative districts and cities of regional subordination and closed administrative-territorial formation became urban districts. A major problem is the fact that over a long period of existence of the administrative districts within the current borders, their population has decreased markedly. Average population districts of the Kirov Oblast is also about twice the size behind Russia. In the most sparsely populated Bogorodsky and Sunsky districts there 4,7 thousand 6.4 thousand people live. The population of the urban districts of the region is almost the same number of municipalities in Russia, but the city district of the strikingly different in size from each other. Thus, at the beginning of 2014 in the Kirov Oblast existed 274 rural and 52 urban settlements, 39 municipalities, and 6 urban districts.

Despite the fact that 2013 was the first year since the beginning of reform, during which in the Kirov Oblast happened further consolidation of municipalities, municipalities existing grid can not be considered stable. Areas where there was a significant (more than twofold) reduction in the number of settlements are fairly evenly distributed across the region, while the processes of population decrease are differentiated through the 


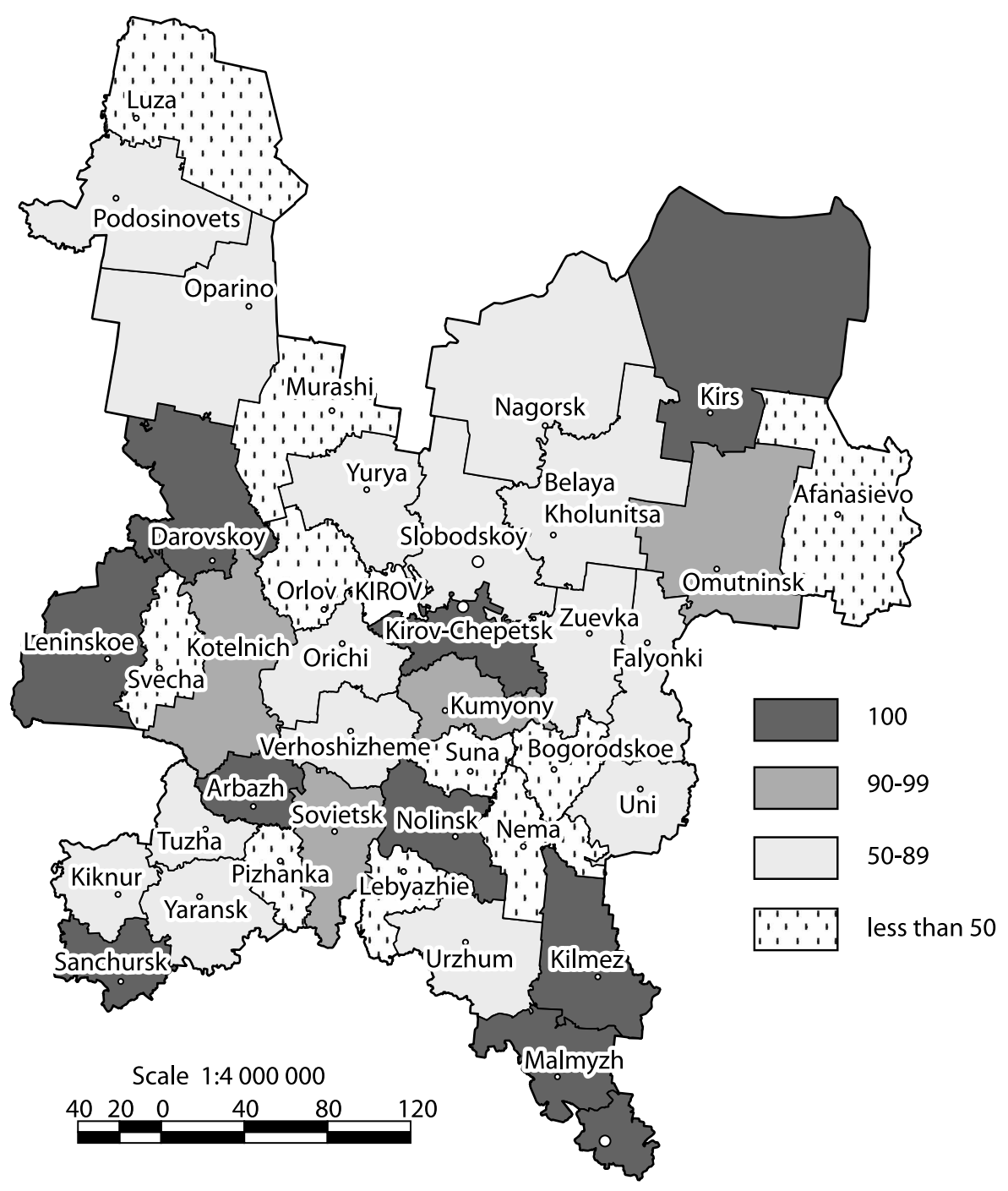

Fig. 4. Changing the number of rural and urban settlements in the Kirov Oblast 2005-2013, \%

«center - periphery». Among the most problematic districts in demographic terms, but in which the number of settlements has not yet changed, include eight districts of the region (Fig. 2 and Fig. 4).

The continuing trend of population decrease in all municipalities, apparently, in the medium term, will require changes in the grid of the second level of municipalities. Thus, according to the Strategy of socio-economic development of the Kirov Oblast until 2020, it should be provides with the optimization of the territorial division, in particular, the association with urban area in municipal districts where the area is considerably more developed than the district and serves as a basis for economic and social development of the territory, moreover, the possible changes in the boundaries of municipalities should be idnetified with a view to reducing their number from the perspectives of economic and social development.
Adaptation options for local government conditions of depopulation would clearance municipal (administrative) districts as units of above munitsipal level control [11]. Municipal districts is objectively folding administrative structures needed to coordinate the activities of the regional authorities of the territory of the county, of adjacent districts, and urban districts, implementation of common inter-municipal projects. Experience of creating such structures available in some regions of Russia (Sverdlovsk Oblast, Stavropol Krai, Altai Krai, Moscow), as well as the need to continue reforms.

The current grid municipalities in the Kirov Oblast and other regions of Russia depopulated with some delay will continue to change in accordance to the population dynamics. Optimization of the municipal unit should go «naturally» and be secondary to be changed in the demographic sphere. Excessive desire of regional authorities 
to reduce the number of municipalities, both first and second level would threaten local authorities distancing from the population and accelerate the

extinction abolished municipalities that would further weaken the regional periphery.

Acknowledgement: This article is supported by Presidential grant for young Russian scientists - PhD number MK-3878.2014.6 "Transformation of the territorial organization of the population and social sphere in depressive region".

\section{References}

1. Ob obshchikh printsipakh organizatsii mestnogo samoupravleniya v Rossiyskoy Federatsii ot 6 oktyabrya 2003. [Federal Law «On General Principles of Local Self-Government in the Russian Federation» of 6 October 2003, No. 131-FZ]. Available at: http:// ivo.garant.ru/document?id=86367\&byPara $=1$.

2. Ob ustanovlenii granits munitsipalnykh obrazovaniy Kirovskoy Oblasti i nadelenii ikh statusom munitsipalnogo rayona, gorodskogo okruga, gorodskogo poseleniya, selskogo poseleniya ot 7 dekabrja 2004. [Law of the Kirov Oblast «On establishing the boundaries of municipalities Kirov region and empowering their status as municipal district, urban district, urban settlements , rural settlement» of 7 December 2004, No. 284- ZO]. Available at: http://base.garant.ru/17122889.

3. Andreyev, A. (2013). Kirovstat: K 2031 godu naselenie Vyatki mozhet sokratitsya na 257 tysyach [Kirovstat: up to 2031 the population could shrink by Vyatka 257 000]. Available at: http://www.rg.ru/2013/04/10/reg-pfo/nasekenie-anons.html.

4. Baboon, R. V. (2013). Organizatsiya mestnogo samoupravleniya [Organization of local government]. Moscow, KnoRus, 273.

5. Glaser, O. B. (2013) Sistema mestnogo samoupravleniya kak sostavnaya chast institucionalnoy sredy rasseleniya v sovremennoy Rossii [The system of local self-government as part of the settlement of the institutional environment in modern Russia]. Voprosy geografii [Problems of Geography]. (vol. 135). Geography of Population and Social Geography. Moscow. «Kodeks» Publishing House, 224-244.

6. Poslanie Prezidenta Federalnomu Sobraniyu 12 dekabrya 2013 goda [Presidential Address to the Federal Assembly. December 12, 2013]. Available at: http://www.kremlin.ru/news/19825.

7. Tatarkin, A. I. (2013). Samorazvitie territorialnykh socialno-ekonomicheskikh sistem kak potrebnost federativnogo obustroystva Rossii [Self-development of regional socioeconomic systems as the need for Russia's federal Development]. Ekonomika regiona [Economy of Region], 4, 9-26.

8. Turgel, I. D. (2013). Formirovanie finansovykh osnov mestnogo samoupravleniya: itogi i perspektivy reform [Formation of financial bases of local government: results and prospects of reform]. Regionalnaya ekonomika: teoriya $i$ praktika [Regional Economy: Theory and Practice], 2, 18-29.

9. Formirovanie mestnogo samoupravleniya v Rossiyskoy Federatsii. 2009-2013. Stat. bull [Formation of local self-government in the Russian Federation. Stat. bull.]. Rosstat, Moscow.

10. Chernyshev, K. A. (2013). Migratsionnye protsessy i migratsionnaya politika v depressivnom regione [Migration processes and migration policy in a depressed region]. Regionalnaya ekonomika: teoriya i praktika [Regional Economy: Theory and Practice], 45, 56-60.

11. Sharygin, M. D. (2010). Mestnoe samoupravlenie: problemy territorialnoy organizatsii i ierarkhizatsii [Local government: the problem of territorial organization and hierarchization]. Vestnik Baltiyskogo federal go universities in. I. Kanta [Bulletin of the I. Kant Baltic Federal University], 3, 51-53.

12. Cameron, R. (2007). Municipal Reform in the Russian Federation and Putin's "Electoral Vertical". Democratization, 15, 2, 191-208.

13. GelMan, V. (2002). The Politics of Local Government In Russia: The Neglected Side Of The Story. Perspectives on European Politics \& Society, 3, 3, 495-508.

\section{Information about the author}

Chernyshev Konstantin Anatolyevich (Kirov, Russia) - PhD in Geography, Associate Professor of the State and Municipal Administration Department, Vyatka State University (36, Moskovskaya St., Kirov, 610000, Russia, e-mail: kochern@rambler.ru). 